\title{
10 Tokyo 2020 and neighborhood transformation
}

\section{Reworking the entrepreneurial city}

\author{
Ralph Lützeler
}

Shortly after Tokyo had been selected as host city of the 2020 Summer Olympics and Paralympics, newspapers all over the world covered the sad story of an elderly citizen named Jinno Kohei. While already being relocated once due to construction activities related to the 1964 Olympics, he - together with another 200 households living in the Kasumigaoka public apartment complex - was asked to move again, this time to make way for the expanded site of the rebuilt Olympic Stadium.

Evictions or displacements of residents are among the usual concomitants of redevelopment projects related to mega-events. It is said that 720,000 people had to move in preparation for the 1988 Seoul Olympics, while the 1996 Atlanta Olympics caused 30,000 residents to leave their homes. ${ }^{1}$ To oppose such forced relocations is often like fighting against windmills. Not only huge financial interests are involved but mega-events are also usually part of a top-priority regional or even national strategy to strengthen the economic base of urban regions, known as "entrepreneurial city politics."

This chapter provides a rough estimate on the extent of residential displacement related to the 2020 Olympics. I show that neighborhood transformation in Tokyo is characterized less by direct and conflictridden evictions than by indirect, gradual, and spatially isolated forms of residential displacement. The decision to host the 2020 Olympics in Tokyo has accelerated the pace of ongoing urban transformation but has not changed its basic character, nor has it initiated any major residential redevelopment project apart from the Olympic Village complex. Tokyo is a far cry from being a socially just city, but the peculiar features of the real estate market - and not the often-alleged "equality" of Japanese society - mitigate the forces of residential displacement inherent in entrepreneurial city politics even when mega-events such as the Olympic Games are involved. 


\section{Tokyo: a dynamic entrepreneurial city surrounded by decline}

Entrepreneurial city politics is a technical term for a shift away from the long-standing managerial role of local governments to provide services, facilities, and benefits to urban citizens. Instead, cities opt for economic growth strategies focusing on the attraction of "external sources of funding, new direct investment, or new employment sources." This policy shift started in the United States in the 1970s, when cities faced the threats of deindustrialization, fiscal constraints, and being surpassed by competing municipalities or regions. The lack of resources to realize economic restructuring on their own account induces city administrations to form public-private partnerships with investors that were granted incentives such as the abolition or weakening of city planning standards, tax exemptions, or the bargain sale of public space - including public housing. To improve the competitive edge of urban areas, "consumer attractions (sports stadia, convention and shopping centers, marinas, exotic eating places) and entertainment (the organization of urban spectacles on a temporary or permanent basis)," have become important elements of urban development strategies. ${ }^{2}$

In Japan, entrepreneurial city politics became finally established when Prime Minister Koizumi (2001-2006) started running the government. In direct response to the increasing international competition among metropolises to attract global finance and business functions, and inspired by the British urban renaissance strategy, the Japanese National Diet passed a Law on Special Measures for Urban Renaissance that became effective in April 2002. This law enabled exemptions from building regulations, abridged permit procedures as well as state-secured interest-free loans and guarantees to be implemented in designated special urban redevelopment districts. In the case of Tokyo, it is intended to both support the repopulation of the city center (by upper-middle class citizens) and attract foreign investors and expatriates to successfully compete with other global cities.

This strong focus on the regeneration of Tokyo has without doubt contributed to the fact that the Japanese capital and its neighboring prefectures are now an island of growth surrounded by a sea of shrinking regions. Since the latter half of the 2000s, population figures for all Japan are on a downward trend due to low birth rates and equally low immigration of foreigners. The commuter belt of Tokyo, i.e. the four prefectures of Saitama, Chiba, Tokyo, and Kanagawa, however, showed an increase from 33.4 million inhabitants in 2000 to 36.6 million in 2019 (an increase of $9.6 \%$ in relative terms). The core city (i.e., the 23 -special-ward area extending over 
just $628 \mathrm{~km}^{2}$ ) absorbed almost half of this increase by growing from 8.1 to 9.6 million residents $(17.6 \%)$, and this trend is forecasted to continue at least for another ten to 15 years. The map of Tokyo wards (see Figure 10.1) further reveals that growth was strongest in the central wards where most designated redevelopment districts are situated. When Tokyo was selected in 2013 to host the Olympics, the construction of highspecification office space and luxury residential towers accelerated and resulted in further population increase, after having experienced a short slump due to the world financial crisis in 2008/9 and the immediate aftereffects of Japan's 2011 triple disaster.

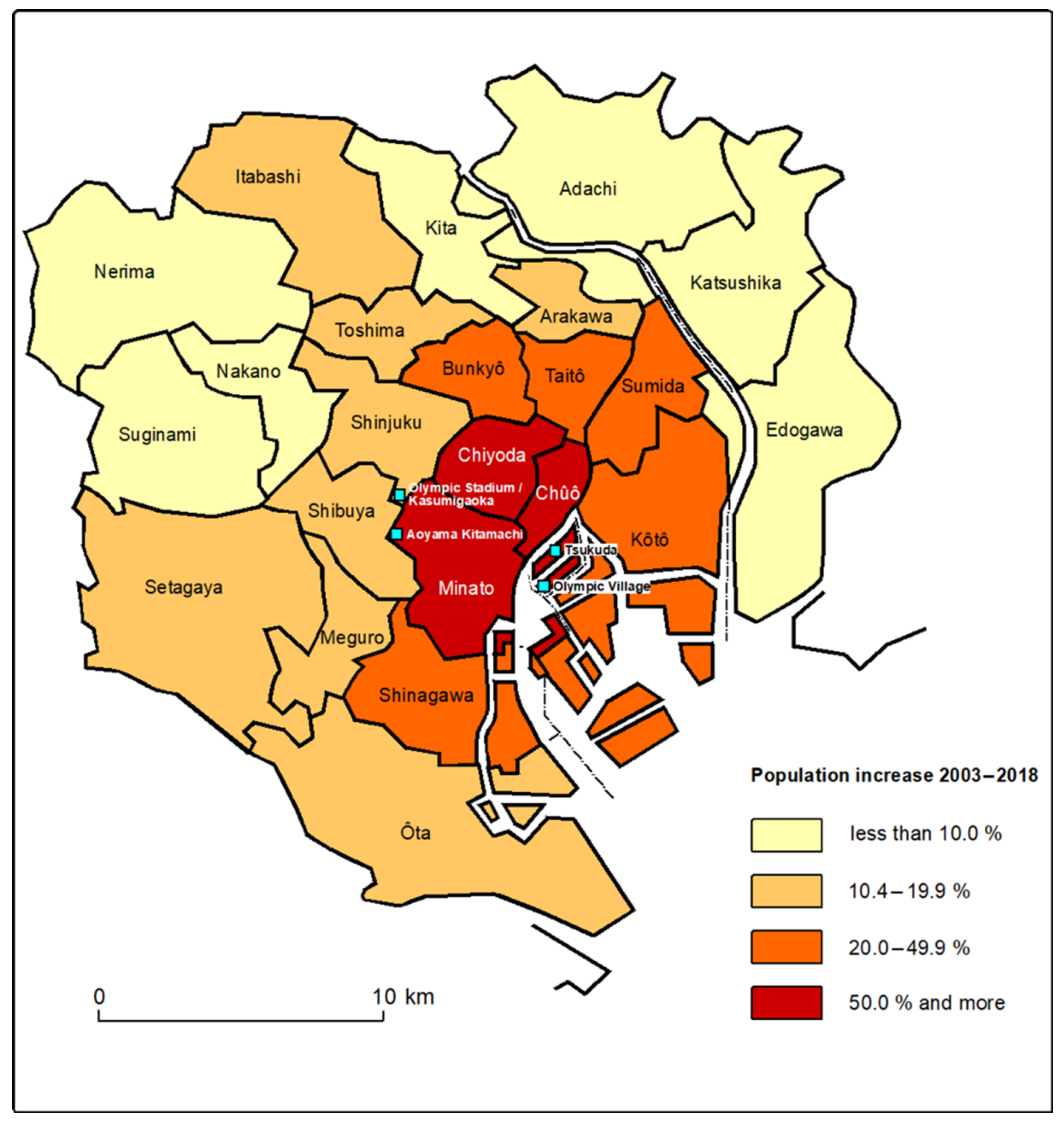

Figure 10.1 Tokyo's population increase 2003-2018 by wards.

Source: Map designed by author. 


\section{Evicted in rare cases, but not abandoned: tenants in public housing complexes}

Dynamic urban redevelopment of this scale might lead to the assumption that residential displacement is widespread in Tokyo. However, this is not the case. First of all, public housing complexes like the Kasumigaoka estate are an exceptional case. Only here Japanese public authorities, in this case the Tokyo Metropolitan Government (TMG), have the power to evict residents. This power is, however, only rarely used against poor households.

Actually, many public housing complexes, which were built during the heyday of the postwar economic miracle, are now in a dilapidated state and beyond repair. In the case of rebuilding, all former tenants still eligible for public housing at the time of demolition have the right to return. Rent increases do occur, but usually of moderate scale. This means that housing standards are improved without displacing the often poor and/or elderly inhabitants. It has to be admitted that these rebuilding activities are not meant as a social corrective, but rather intended to generate a lively, safe atmosphere in order to dilute existing social problems and maintain the global attractiveness of Tokyo. ${ }^{3}$ Thus, these policies are not contravening the logics of entrepreneurial city politics, but they do not cause large-scale displacement of poor households.

The 1963-built Kasumigaoka complex had been on the list for demolition years before it became clear that Tokyo would host the Olympics. Due to the planned expansion of the stadium premises, it was decided not to rebuild it. Instead, tenants were offered housing in other public complexes. While this might lead to disadvantages, at least they were not left to their own devices. Another public housing complex mentioned in the context of tenant displacement due to the Olympics is Aoyama Kitamachi, scheduled for completion in early $2020 .{ }^{4}$ Here the total amount of social housing will decrease by about 300 units from its previous form. However, the renewal project had been designed by TMG already in 2006 with the aim to adjust the social composition of the area to the wealthy neighborhoods surrounding the complex, and thus has no causal relationship to hosting the 2020 Games. On the whole, there is only scant evidence that the Olympics have directly led to displacements of tenants from public housing in Tokyo.

\section{Gentrification Tokyo-style}

As mentioned above, the volume of construction activities has soared in Tokyo following the selection in 2013, leading to voices complaining about the destruction of traditional neighborhoods. However, many such 
projects are carried out in easy-to-access locations such as the vicinity of local train stations far away from the sports venues of the Olympics. In most of these cases as well, planning procedures started before 2013, meaning that the Olympics may have accelerated the pace of neighborhood transformation but not initiated the renewal projects.

Apart from this, the number of housing units created by urban redevelopment projects located on industrial wasteland or newly reclaimed land at Tokyo's waterfront by far outnumbers those associated with the complete demolition of neighborhoods. In Japan, property rights on land are spatially fragmented and highly protected, requiring lengthy negotiations which leads many corporate developers to divert their energy to unused tracts of land provided by the TMG or other public actors. Such upgrading of central urban districts by new, stylish housing complexes on abandoned sites is common in many other parts of the world as well and is known by the term "new-build gentrification."

In this way, numbers of tenants directly displaced from privately rented apartments are kept comparatively low in Tokyo. In the long run, however, new-build gentrification causes displacement of lower-income groups as well, either by stimulating an increase in real estate prices of the surrounding area or by altering the socio-cultural ambience of the district, thus alienating many of the established residents from their neighborhood. ${ }^{5}$ There are indications that such is the case in the area dealt with in the following section.

\section{The Olympic Village and its surroundings: a redevelopment hotspot}

The Olympic Village is a typical - albeit somewhat over-dimensional case of new-build gentrification. It is constructed on a formerly unused 13.4-hectare area at the southwestern tip of Harumi Island in the innermost part of the waterfront area (see Figure 10.2). The complex is thus located at the intersection between the so-called "Heritage Zone" on the mainland and the "Tokyo Bay Zone," the way the Olympic competition sites have been named. The project includes, among other facilities, 21 residential buildings ranging from 14 to 18 stories, which will accommodate the 17,000 athletes and guests. A Bus Rapid Transit (BRT) system is intended to connect athletes (and eventually commuters, the post-Olympic future residents) with the mainland. Yet due to delays in construction, there are strong doubts whether this sole public transport connection with the city center will be ready for use in 2020. After the Games, the building consortium, which includes almost all big developers of the country, will add two 50 -story buildings to the complex, increasing the number of apartments 


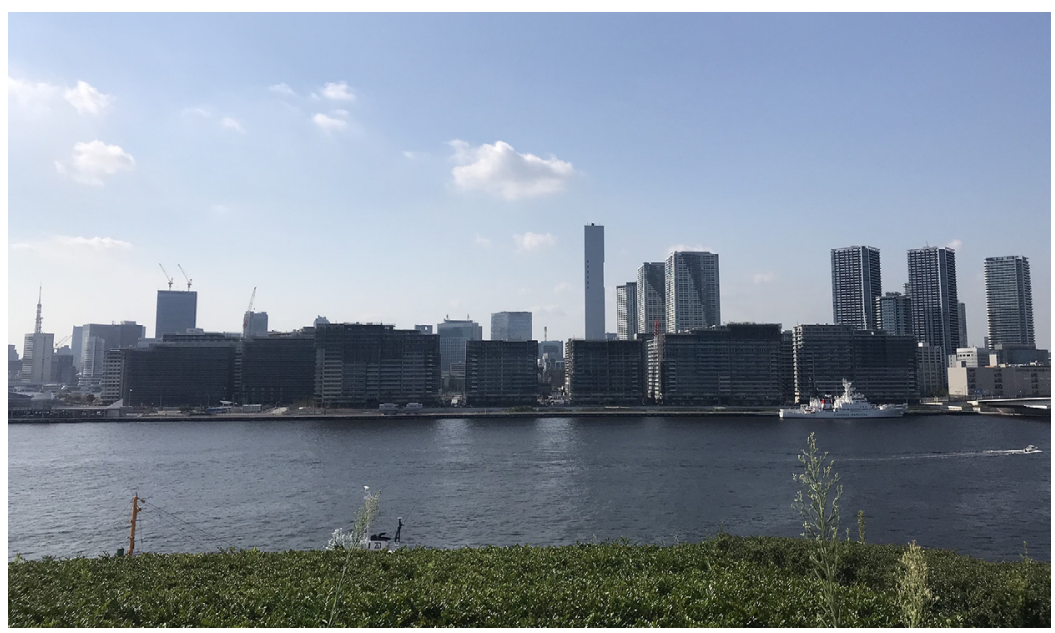

Figure 10.2 The Olympic Village, under construction in 2019.

Source: () Barbara Holthus.

ready for sale or rent to 5,650 units. Since this would be equal to about $30 \%$ of the annual supply of new apartments in Tokyo, there are fears that there will not be enough interested residents to move in. ${ }^{6}$

The real estate market of the surrounding area, that is, the islands of Tsukuda (including the districts of Tsukishima and Kachidoki) and Harumi, all part of Chuo Ward, has not been left unaffected by the construction of the Olympic Village and its central location between the two venue zones. Since 2013, land prices rose much faster here than in any other area of Tokyo. Again, however, the Olympics have only accelerated a trend that had started earlier. The population on the two islands jumped from 42,096 in 2005 to 57,551 in 2013 and 74,222 in 2019. Most of the increase was due to the completion of large condominium complexes on hitherto unused land. Nevertheless, social upgrading as defined by a disproportionate rise in the proportion of residents in higher professions can be recognized in several pre-existing neighborhoods of the area as well, suggesting gradual - and moderate - displacement of poor citizens or average earners by a wealthier clientele.

Thus, Tokyo is not a tenants' paradise. Compared to other global cities, however, direct forms of residential displacement are not very common, and even hosting the 2020 Summer Olympic Games obviously has not brought change to this situation. Urban inequality in Tokyo rather 
manifests itself in the increasing wealth gap between inner- and outerTokyo due to the disproportionate influx of upper-middle class residents into the central wards, including the waterfront area.

\section{Notes}

$1 \mathrm{http}: / /$ thediplomat.com/2013/09/will-the-2020-olympics-really-help-tokyo/.

2 All citations in this paragraph were taken from: Harvey, David. 1989. "From managerialism to entrepreneurialism: The transformation in urban governance in late capitalism." Geografiska Annaler. Series B, Human Geography 71(1): 3-17.

3 Lützeler, Ralph. 2011. "Left behind in the global city: Spaces and places of ageing and shrinking in the Tokyo metropolitan area." In Coulmas, Florian, Ralph Lützeler (eds). Imploding populations in Japan and Germany - a comparison. Leiden, Boston: Brill: 473-491.

4 Mori, Chikako. 2017. "Social housing and urban renewal in Tokyo: From postwar reconstruction to the 2020 Olympic Games." In Watt, Paul, Peer Smets (eds). Social housing and urban renewal: A cross-national perspective. Bingley: Emerald: 277-309.

5 Lützeler, Ralph. 2008. "Population increase and 'new-build gentrification' in central Tokyo." Erdkunde 62(4): 287-299.

$6 \mathrm{https}: / /$ resources.realestate.co.jp. 